\title{
EFFECT OF PEDIOCOCCUS ACIDILACTI ON ENZYMATIC ANTIOXIDANT, PATHOLOGY AND BROILERS MEAT QUALITY UNDER SALMONELLA INFECTION
}

\author{
BAZ G.B. ${ }^{*}$; NAGWAN M. EL- HABASHI ${ }^{* *}$;EL-KEREDY M. S. ABEER ${ }^{* * *}$; HEGAZY A. M. ${ }^{* * * *}$; \\ BARAKAT, M. ${ }^{* * * * *}$; and SABREEN E. FADL \\ ${ }^{*}$ Food hygein Dept., Animal Health Research Institute - Kafrelshikh, Egypt. \\ ${ }_{* * *}^{*}$ Pathology Dept., Fac. Vet. Med., Kafrelshikh University, Egypt. \\ ${ }^{* * *}$ Nutrition and clinical nutrition Dept., Animal Health Research Institute - Kafrelshikh, Egypt. \\ ${ }_{* * * * * *}^{* * *}$ oultry diseases Dept., Animal Health Research Institute - Kafrelshikh, Egypt. \\ ${ }^{* * * * *}$ Biochemistry department, Animal Health Research Institute - Kafrelshikh, Egypt. \\ * Correspon auther: Sabreen E. Fadl, researcher of Biochemistry, Animal Health Research Institute, Kafrelshikh. Egypt. \\ Email: nourmallak@yahoo.com
}

\section{ABSTRACT}

Received at: 31/3/2014

Accepted: 2/6/2014
One hundred and twenty five three days-old broilers chick were used in this study to evaluate growth performance of $S$. enteritidis colonization, antioxidant, lipid peroxidation, meat quality and histopathological findings of broilers chick supplemented with Pediococus and challenged with Salmonella infection. The broilers chick were divided into four groups, control group without infection, Pediococcus group without infection, group infected with salmonella and Pediococcus group with Salmonella infection. The results indicated that the use of Pediococcus acidilactici was without affect on the growth performance, improved antioxidant, decreased lipid peroxidation, improved quality of meat and decreased histopathological lesion of Salmonella.

Key words: Pediococcus acidilacti, Broilers, Salmonella.

\section{INTRODUCTION}

The vertebrate innate immune system protects the organism by producing reactive oxygen species (ROS) in a process called oxidative burst. These oxygen species are highly reactive and destroy pathogens by damaging their proteins, lipids and DNA. These reactive species are not pathogenspecific and can also damage host tissues if there are not enough protective antioxidants present (Sepp et al., 2012). Also in numerous physiological and pathological states, the systemic amounts of free nonoxygen radicals and reactive oxygen species (ROS) are elevated. Lipid peroxidation is one of the best parameter used for indicating the level of ROSinduced systemic biological damage. One lipid peroxidation end-product, malondialdehyde (MDA), is isolated from urine, blood and tissues and is used as a biomarker for radical-induced damage. Chickens possess both enzymatic and non-enzymatic antioxidant mechanisms of defence that prevent ROS formation or limit their toxic effects. Superoxide dismutase (SOD) and catalase (CAT) are antioxidant enzymes involved in endogenous antioxidant defences against ROS (Georgieva et al., 2006).

Lipids are an important component of meat and contribute to several desirable characteristics of meat and meat products. Lipids are important to enhance the flavour and aroma profile of meat and also increase the tenderness and juiciness of meat.
However, it is generally accepted that lipid oxidation is the primary process responsible for quality deterioration of meat during storage (Weber and Antipatis 2001). Membrane lipids are protected against oxidative attack by naturally occurring antioxidants (Jensen et al., 1995). The oxidative status of the feed given to animals has a significant influence on the final meat quality. Meat obtained from animals grown on oxidized feed has a significantly lower oxidative status compared to the animals fed on a feed of good oxidative status (Tesoriere et al., 2002).

Reactive oxygen species (ROS) are implicated in several pathophysiological conditions. ROS are known to attack almost all molecules of the cells including membrane lipid peroxides (Koinarski et al., 2006). Mathew et al. (2007) reported a concomitant increase in lipid peroxidation and a drop in antioxidant enzyme activities of SOD, CAT, Gpx and Glutathion-S- transferase in the digestive gland, muscle and haemolymph of P. monodon following infection with white spot syndrome virus (WSSV). Also, Mehta et al. (1998) reported a decreased endogenous intestinal protection against ROS in $S$. typhimurium-mediated infection, which could contribute to the pathogenesis of the disease.

Probiotics are harmless bacteria that help the well being of the host animal and contribute, directly or indirectly to protect the host animal against harmful 
bacterial pathogens (Gatesoupe, 1999). Oral supplementation of Ped. acidilactici lactic acid bacteria modulates intestinal bacterial communities in on-growing tilapia and also stimulates some aspects of the nonspecific immune response where Ped. acidilactici colonized the intestinal tract and significantly affected the intestinal microbial communities (Ferguson et al., 2010). Beneficial microflora promote gut development and health by influencing enterocyte turnover, competing with pathogenic bacteria for nutrients and binding sites, and producing bacteriostatic compounds that limit the growth of pathogenic bacteria (Farthing 2004).

Lactic Acid Bacteria (LAB) have antioxidant activities (Kullisaar et al., 2002) and some studies showed an enhancement of total antioxidant status (TAS) in blood of humans fed LABs (Kullisaar et al., 2003). Treatment of Pediococcus acidlactici-based probiotic on intestinal villus height of broiler chickens increased villus height in duodenum and ileum when compared with control (Taheri et al., 2010). Pediococcus acidilactici enhanced the colonization and adhesion of probiotics on the surface of intestines besides increasing the density, length and width of intestinal villus resulting in better performance and meat quality in broilers (Satheesh et al., 2012).

\section{Aim of the work:-}

The present study is conducted to evaluate the effect of Pediococcus acidi lacticae on meat quality and villius hights in broilers chicken and to investigate the relationship between infection and antioxidant.

\section{MATERIALS and METHODS}

This study was conducted in the animal health research institute - kafrelshikh, Egypt.

\section{Experimental design:}

A total of 125 three days -old chicks assumed to be free of salmonella by (15 fecal swabs and organs culture from 5 sacrificed chicks) were obtained from the General Egypt Poultry Organization and classified into 4 groups. The chicks were housed in clean well-ventelated room under sanitary hygienic, good mangement and kept either on a basal ration (as shown in the table 1) which was formulated according to NRC (1994) or on a basal ration with Pediococcus acidilactici (probiotic) at a rate of $100 \mathrm{mg} / \mathrm{kg}$ ration for 35 days for performance and biochemistry and 40 days for meat quality. All groups chicks were vaccinated against ND and IBD at $7 \& 12$ day respectively. Experimental infection with overnight broth culture of $S$. enteritidis at 2 week of age was done as shown in the table (2)

\section{Bacterial infection:}

Experimental infection was done via oral route with 1 $\mathrm{ml}$ containing $3 \times 10^{8}$ of $S$. enteritidis at 15 day -old.
This strain was supplied by A.M. Hegazy (Animal Health Research Institute, Kafr El-Sheikh Regional lab).

\section{Measurements:}

Growth performance parameters:

Body weight (BW), feed conversion ratio (FCR), feed intake (FI) and mortality rate were recorded weekly.

\section{Sampling and antioxidant and lipid peroxidation measured:-}

Blood was collected through slaughtering. $1 \mathrm{ml}$ of this blood was mixed immediately in Ependorf tubes with EDTA and used for determining of reduced glutathione (Beutler et al., 1963). The rest of blood after coagulation was centrifuged at $3,000 \times \mathrm{g}$ for 15 minutes for separation of serum (stored deep freezer until use) for detecting superoxid dismutase (SOD) (Nishikimi et al., 1972), catalase (CAT) (Ashru and Sinha 1971) and Lipid peroxidation (represented in malonaldehyde $=$ MDA) (Beuge and Aust 1978).

\section{S. enteritidis colonization:}

Fecal shedding and organ colonization were recorded weekly for three weeks. Confirmation of the results of colonization and shedding was done by $S$. enteritidis antiserum prepared in rabbit as described by Seleim (1999).

\section{Symptoms and P. M lesions:}

All groups were kept under observation for symptoms, post mortum (P.M) and mortality along the experimental period.

\section{Chemical analysis of feed and meat: -}

The proximate analysis of feed sample moisture, crude protein $(\mathrm{CP})$, ether extracts (EE), crude fiber $(\mathrm{CF})$, total ash content were determined according to A.O.A.C. (1990).

The examined samples of chicken meat were analyzed for determination of moisture, protein, fat, ash and carbohydrate by using the standard method recommended by Association of Official Analytical Chemists "AOAC" (2000) as follow:

\section{Determination of moisture $\%$ :}

A dish was dried in an oven and cooled in the desiccator. Approximately $2 \mathrm{~g}$ of sample were weighed into the dish and dried in the oven at $102^{\circ} \mathrm{C}$ with the lid alongside for 2 hours. The dish was covered with the lid, and transferred to the desiccator and when the dish completely cooled, it was weighed, then heated in the oven half-an-hour and reweighed. Repeat until successive weights do not differ.

Moisture \% $=\frac{\text { Weight lost } \times 100}{\text { Weight of sample }}$




\section{Determination of protein $\%$ :}

The weighed samples were placed in Kjeldahl flask containing mercury oxide (catalyst) and potassium sulphate (increasing boiling point). Concentrated sulphuric acid was added, and the mixture was heated and boiled until the sample was completely digested and yielded ammonia. The flask was cooled, the solidified content (including a sulphide to precipitate the mercury) was added and, the released ammonia was distilled via a condenser into a boric acid solution containing acid-base indicator. The collected ammonia was titrated with standardized hydrochloric acid. So the amount of ammonia present could be detected, and thus the amount of nitrogen can be calculated.

\section{Crude protein $\%=$ nitrogen $\%$ x 6.25 .}

\section{Determination of fat $\%$ :}

A weighed sample was dried at $60{ }^{\circ} \mathrm{C}$ for 72 hours. The dried sample was exactly weighed and wrapped carefully in a filter paper. Such prepared sample was used in determination of fat $\%$.

Soxhlet flask containing $75 \mathrm{ml}$ ether was placed on the electrical heater; the sample was placed in the extractor which was fixed tightly over the Soxhlet flask. Then, the condenser was fixed over the extractor. When heating occurred ether will be evaporated and raised up through the outside capillary tube to the condenser, where it was recondensed to liquid again under the effect of water current in the condenser, and down set on the sample dissolving apart of the fat. Ether was accumulated in the extractor until siphoning occurred where the ether returned to the flask again with the dissolved fat. This process was repeated until all fat in the sample will be extracted this take about 6 hours. Repeat weighing the sample after drying to record the loss of weight and fat $\%$ was calculated.

\section{Determination of ash \%:}

A weighed sample was dried at $60{ }^{\circ} \mathrm{C}$ for 72 hours. In a porcelain crucible of known weight, the known weight of dried sample was placed and the crucible was transferred into muffle furnace at $450^{\circ} \mathrm{C}$ to free ash from carbon and inorganic matters. The process was continued for about 6 hours then the crucible was cooled, desiccated and weighed. This technique of heating and weighing was repeated several times till reaching 2 equal successive weights. Therefore, the ash \% was calculated as follow:

Ash $\%=$ difference between crucible with ash and empty crucible.

5. Determination of Carbohydrate \%:

Each sample was estimated for its moisture, protein, fat, crude fiber and ash content. Accordingly, carbohydrate $\%$ was calculated by the difference from the following equation:
Carbohydrate $\%=100-($ moisture $\%+$ protein $\%$ + fat $\%$ + crude

$$
\text { fiber } \%+\operatorname{ash} \%)
$$

\section{Determination of pH (Pearson 1984):}

In a blender, approximately $10 \mathrm{~g}$ of sample were blended in $10 \mathrm{ml}$ of distilled water. The homogenate was left at room temperature for 10 minutes with continuous shaking. The $\mathrm{pH}$ value was determined by using an electrical pH meter (Bye model 6020, USA).

\section{Histopathological findings of chicken supplemented with pediococus and challenged with salmonella infection: \\ Necropsy and histopathology}

After necropsy, small pieces of liver, intestine and spleen were dehydrated and embedded in paraffin wax by routine methods. They were then sectioned at $3 \mu \mathrm{m}$, stained with haematoxylin and eosin (HE), and examined by light microscopy.

\section{Statistical analysis:}

The obtained numerical data were statistically analyzed using S.P.S.S., (1997) for one-way analysis of variance. When F- test was significant, least significant difference was calculated according to Duncan (1955).

\section{RESULTS}

\section{Symptoms and P. M lesions:}

Experimental infection revealed suggestive clinical and gross pathological lesions, in the form of depression which appeared after $48 \mathrm{~h}$ post infection and was associated with whitish diarrhea unabsorbed yolk sac, distended gall bladder, enlarged congested liver, distended cecum and sometimes cecal core and the appearance of intestinal ulcer (characteristics for ND specifically in the duodenum) were obvious in salmonella infected group. All the previously mentioned symptoms and P. M changes were less prominent in group of pedicoccus with infection in comparison with the salmonella infected group. This may be attributed to the effect of pedicoccus sp. No significant variation in mortality as it was $3 \& 2$ chicks for each of salmonella infected group \& group of pedicoccus with infection respectively (table 4). Deaths were restricted to 1 st 5 days pi.

\section{Growth performance:}

Table (5) showed the growth performance parameters, where the final body weight was significantly decreased $(\mathrm{P}<0.05)$ in groups of pediococcus with or without infection compared with the control group without infection. Salmonella infected group significantly decreased $(\mathrm{P}<0.05)$ in body weight when compared with the control without infection and pediococcus groups with or without infection. 
The feed conversion ratio in the different groups are presented in table (5). It is clear that the general mean of feed conversion in Salmonella infected group increased FCR $(1.79 \pm 0.13 \mathrm{a})$ versus $(1.66 \pm 0.04 \mathrm{a})$, $(1.63 \pm 00.009 \mathrm{a})$ and $(1.58 \pm 0.1 \mathrm{a})$ in control negative; pedicoccus- salmonella; and pedicoccus control groups, respectively but not significant $(\mathrm{P}<0.05)$.

\section{Antioxidant and lipid peroxidation measurements:-}

Table (6) showed enzymatic antioxidants, GSH and MAD, which presents significant decreased in GSH $(1.79 \pm 0.01 \mathrm{~b})$, CAT $(22.93 \pm 1.00 \mathrm{c})$ and SOD $(117.21+19.88 \mathrm{~b})(\mathrm{P}<0.05)$ in salmonella infected group without probiotic compared with other groups. Regarding the effect of probiotic, Pediococcus group without infection significantly increased $(\mathrm{P}<0.05)$ CAT activity $(62 \pm 2.08$ a) compared with the other groups and insignificantly increased $(\mathrm{P}<0.05)$ SOD in Pediococcus groups with and without infection compared with the control non infected group $(161.04+23.79 \mathrm{a})$, insignificantly increased $(\mathrm{P}<$ $0.05)$ GSH (3.57 \pm 0.18 a) in Pediococcus group without infection compared with the control non infected group ( $3.50 \pm 0.15 \mathrm{a})$ and the pediococcus infected one $(3.27 \pm 0.57 \mathrm{a})$. SOD

Meanwhile MAD significantly increased $(\mathrm{P}<0.05)$ in salmonella infected group (10.9 $\pm 0.92 \mathrm{a})$. Regarding the effect of probiotic, pediococcus group without infection $(2.9 \pm 0.35 \mathrm{~b})$ insignificantly decreased MDA $(\mathrm{P}<0.05)$ compared with the control non infected group $(3.47 \pm 0.26 \mathrm{~b})$ and the Pediococcus infected one (4.1 $\pm 0.67 \mathrm{~b})$.

\section{Chemical analysis of meat: -}

Table (7) showed the chemical composition of broiler meat where the average water content was significantly decreased $(\mathrm{P}<0.05)$ in the control group without infection and in the Pediococcus group without infection compared with control infected group and Pediococcus infected one, where the lower percentage in control group without infection (72.43 $\pm 0.30 \mathrm{~b}$ ) and the higher percentage in salmonella infected group. While, the obtained our results with respect to protein showed significant increase $(\mathrm{P}<$ 0.05 ) in protein $\%$ in the Pediococcus group without infection (21.6 $\pm 0.38 \mathrm{a})$ compared with the salmonella infected group and the Pediococcus infected one, and non significant $(\mathrm{P}<0.05)$ increased about forth control group without infection (20.73 \pm $0.35 \mathrm{ab}$ ) but without significant. Fat \% showed lower $\%$ in the groups receiving Pediococcus with $(2.9 \pm$ $0.19 \mathrm{a})$ or without infection $(2.88 \pm 0.17 \mathrm{a})$ compared with the control groups with $(3.03 \pm 0.17 \mathrm{a})$ or without infection $(3.38 \pm 0.13 \mathrm{a})$ without significance. Regarding to $\mathrm{PH}$ in the different groups, table (7) showed that a significant increased in $\mathrm{PH}$ in the salmonella infected group (5.95 $\pm 0.04 \mathrm{a})$ compared with the control without infection $(5.81 \pm 0.02 \mathrm{c})$ and the Pediococcus without infection $(5.77 \pm 0.02 \mathrm{~cd})$ and in the Pediococcus infected one $(5.86 \pm 0.03 \mathrm{bc})$. Comparing between the control group without infection and the Pediococcus group without infection, there was insignificant decreased in $\mathrm{PH}$ in the Pediococcus without infection group. Table (7) showed insignificant decreased in ash $\%$ in the Pediococcus groups with $(1.6 \pm 0.19 \mathrm{a})$ or without $(1.38 \pm 0.18 \mathrm{a})$ infection compared with the control groups with $(1.58 \pm 0.19 \mathrm{a})$ or without infection (1.55 $\pm 0.34 \mathrm{a})$. Meanwhile carbohydrate $\%$ non significant decreased in the salmonella infected group, and the Pediococcus without infection compared with the control group without infection but significantly decreased in the Pediococcus with infection compared with the control without infection.

\section{S. enteritidis colonization:}

$S$. enteritidis differed in their colonization in different organs. It shows the rates of $60,40,33$, and $33 \%$ for each of intestine, liver, spleen and gall bladder, respectively (table, 8). S. enteritidis was capable to colonize different organs with different rates (Table, 8) intestine, 60 vs. $30 \%$, liver, 40 vs. $13 \%$, spleen, 33 vs. $20 \%$ and gallbladder, $33 \mathrm{vs} .13 \%$ in each salmonella infected control group and Pediococcus vs. salmonella group, respectively.

\section{Histopathological findings of chicken supplemented with Pediococcus and challenged with salmonella infection:}

In group 1(control negative, not received Pediococcus or salmonella infection), no detectable pathological changes were observed in the examined organs including liver (Fig.1a), intestine (Fig.1b) and spleen (Fig.1c). Group 2 (received Pediococcus without exposed to infection), liver was completely normal and Kuffer's cells granuloma were observed (Fig.2a). Intestine was normal with elongation of the villi (Fig.2b). Spleen showed increase in lymphocytic cells population in the white bulb (Fig.2c).

In group 3 (not received Pediococcus and exposed to salmonella infection), the liver showed marked congestion (Fig.3a1,2), in addition to hemorrhage (Fig.4a) was observed especially subcapsular in most of the cases. Portal mononuclear cells and heterophils infiltrations was also observed. In addition to, the previously mentioned lesions, focal necrosis of the hepatic cells infiltrated and surrounded with mononuclear cells and heterophils was detected in few cases with hepatic cell regeneration (Fig.5a). The intestine showed enteritis (Fig.3b1,2) in most of cases characterized by shortening, thickening and adhesion of the villi, degeneration and necrosis of the covering epithelium of mucosa together with marked congestion and marked heterophils infiltrations in the lamina propria and submucosa. Goblet cells hyperplasia was observed in some sections. The spleen showed moderate lymphoid depletion and 
congestion as well as degeneration and depletion of lymphoid follicles (Fig.3c1,2), in group 4 (received Pediococcus and exposed to Salmonella infection), the liver in most of the cases was almost completely normal except very mild congestion (Fig.6a) which tended to be moderate in one case and focal mild perivascular mononuclear cells collections which in few cases were admixed with few heterophils were also observed (Fig.7a). Intestine was almost completely normal and elongation of the villi was observed in most of the cases. However, mild degeneration, thickening and necrosis of villi (Fig.4b) as well as moderate congestion and pyre's patches hyperplasia (Fig.5b) were observed in few sections. Spleen showed normal lymphocytic cells population in the white bulb in most of the cases and lymphoid follicles depletion in one case.

Table 1: Ingredients and nutrients (calculated) of 2 the basal experimental diets for the broilers.

\begin{tabular}{|c|c|c|}
\hline \multirow[t]{2}{*}{ Items } & \multicolumn{2}{|c|}{ Experimental diets } \\
\hline & Starter & Grower and finisher \\
\hline \multicolumn{3}{|l|}{ Ingredient \% } \\
\hline Yellow corn, $(8.5 \%)$ & 53.00 & 59.50 \\
\hline Soybean meal, (44\%) & 29.26 & 29.00 \\
\hline Corn gluten meal, $(62 \%)$ & 9.00 & 3.427 \\
\hline Sun flower oil & 4.50 & 4.50 \\
\hline Dicalcium phosphate & 1.80 & 1.30 \\
\hline Limestone, ground & 1.30 & 1.30 \\
\hline Lysine & 0.08 & 0.29 \\
\hline DL-Methionine & 0.10 & 0.044 \\
\hline Common salt & 0.40 & 0.40 \\
\hline Choline chloride, $50 \%$ & 0.26 & 0.20 \\
\hline Trace minerals and vit. premix & 0.30 & 0.30 \\
\hline \multicolumn{3}{|c|}{ Values between parentheses are determined crude protein content $(\mathrm{N} \times 6.25)$. } \\
\hline \multicolumn{3}{|c|}{ Nutrient (Calculated) } \\
\hline & Starter & Grower and finisher \\
\hline Crude protein, $\%$ & 23.1138 & 20.0027 \\
\hline $\mathrm{ME},(\mathrm{kcal} / \mathrm{kg})$ & 3204.813 & 3205.0426 \\
\hline Calcium, $\%$ & 0.99 & 0.90 \\
\hline Available phosph., \% & 0.47 & 0.37 \\
\hline Lysine & 1.10 & 1 \\
\hline Methionine & 0.51 & 0.38 \\
\hline
\end{tabular}

Table 2: Experimental design for the broilers groups.

\begin{tabular}{|c|c|c|c|}
\hline Group No. & Diet type & Pedicoccus supplementation* & S.enteritidis infection* \\
\hline 1 & Basal diet & - & - \\
\hline 2 & $"$ & $100 \mathrm{mg} / \mathrm{kg}$ ration & - \\
\hline 3 & $"$ & - & + ve \\
\hline 4 & $"$ & $100 \mathrm{mg} / \mathrm{kg}$ ration & $+\mathrm{ve}$ \\
\hline
\end{tabular}

* Pedicoccus is a Probiotic (Bactocell) a commercial product each 1gm contains 1x109

CFU. EGAVET, Giza, Egypt 
Assiut Vet. Med. J. Vol. 60 No. 141 April 2014

Table 3: Chemical composition of the experimental diets.

\begin{tabular}{|c|c|c|}
\hline & \multicolumn{2}{|c|}{ Experimental diets } \\
\hline & Starter & Grower and finisher \\
\hline \multicolumn{3}{|c|}{ Chemical composition * } \\
\hline Dry matter, $\%$ & 89.60 & 89.69 \\
\hline Moisture, $\%$ & 10.40 & 10.31 \\
\hline $\mathrm{CP}, \%$ & 21.87 & 19.16 \\
\hline EE, \% & 5.64 & 5.99 \\
\hline Ash, $\%$ & 6.81 & 6.89 \\
\hline $\mathrm{CF}, \%$ & 3.02 & 3.43 \\
\hline NFE, $\%$ & 52.26 & 54.22 \\
\hline ME,(Kcal/Kg) & 3147.1281 & 3176.7282 \\
\hline
\end{tabular}

*Analysed values

The used permix (multimix broiler) without choline composed of vitamin A $12000000 \mathrm{IU}$, vitamin D3 2200000 $\mathrm{IU}$, vitamin E $10000 \mathrm{mg}$, vitamin K3 $2000 \mathrm{mg}$, vitamin B1 $1000 \mathrm{mg}$, vitamin B2 $5000 \mathrm{mg}$, vitamin B6 $1500 \mathrm{mg}$, vitamin B12 $10 \mathrm{mg}$, Niacin $30000 \mathrm{mg}$, Biotin $50 \mathrm{mg}$, Folic acid $1000 \mathrm{mg}$, pantothenic acid $10000 \mathrm{mg}$, Iron $30000 \mathrm{mg}$, Manganese $60000 \mathrm{mg}$, Copper $4000 \mathrm{mg}$, Zinc $50000 \mathrm{mg}$, Iodine $1000 \mathrm{mg}$, Cobalt $100 \mathrm{mg}$, Selenium $100 \mathrm{mg}$, Calcium carbonate $(\mathrm{CaCo} 3)$ carrier to $3000 \mathrm{~g}$.

Table 4: Effect of pediococcus acidi lactici supplementation without or with SE infection on mortality rate post infection.

\begin{tabular}{lccc}
\hline parameters & Supplementation & Without infection & With SE infection \\
\hline Total No. & Control & 25 & 25 \\
& pediococcus acidi lactici & 25 & 25 \\
\hline \multirow{2}{*}{ Dead No. } & Control & 0 & 3 \\
\cline { 2 - 4 } & pediococcus acidi lactici & 0 & 2 \\
\hline \multirow{2}{*}{ Survival $\%$} & Control & $100 \%$ & $88 \%$ \\
\cline { 2 - 4 } & pediococcus acidi lactici & $100 \%$ & $92 \%$ \\
\hline Mortality $\%$ & Control & $0 \%$ & $12 \%$ \\
\cline { 2 - 4 } & pediococcus acidi lactici & $0 \%$ & $8 \%$ \\
\hline
\end{tabular}

$\mathrm{SE}=$ Salmonella Entritidis

Table 5: Effect of pediococcus acidi lactici supplementation without or with SE infection on growth performance of broiler chicks.

\begin{tabular}{lccc}
\hline \multicolumn{1}{c}{ parameter } & Supplementation & Without infection & With SE infection \\
\hline & Control & $56 \pm 1.32 \mathrm{a}$ & $56 \pm 1.32 \mathrm{a}$ \\
\cline { 2 - 4 } Initial B.W. & pediococcus acidi lactici & $53 \pm 0.87 \mathrm{a}$ & $53 \pm 0.87 \mathrm{a}$ \\
\hline & Control & $1439.1 \pm 0.64 \mathrm{a}$ & $1211.1 \pm 0.59 \mathrm{c}$ \\
\cline { 2 - 4 } Final B. W. & pediococcus acidi lactici & $1405 \pm 0.59 \mathrm{~b}$ & $1397.3 \pm 0.64 \mathrm{~b}$ \\
\hline & Control & $1.66 \pm 0.04 \mathrm{a}$ & $1.79 \pm 0.13 \mathrm{a}$ \\
\cline { 2 - 4 } FCR & pediococcus acidi lactici & $1.58 \pm 0.1 \mathrm{a}$ & $1.63 \pm 00.009 \mathrm{a}$ \\
\hline $\begin{array}{l}\text { B. W. }=\text { body weight } \\
\text { Values are expressed as } \\
(\mathrm{p} \leq 0.05) .\end{array}$ & $\begin{array}{l}\text { FCR }=\text { feed conversion ratio } \\
\text { menn }\end{array}$ & &
\end{tabular}


$\underline{\text { Assiut Vet. Med. J. Vol. } 60 \text { No. } 141 \text { April } 2014}$

Table 6: Effect of pediococcus acidi lactici supplementation without or with SE infection on antioxidant of broiler chicks.

\begin{tabular}{lccc}
\hline Parameter & Supplementation & Without infection & With SE infection \\
\hline Whole blood & Control & $3.50 \pm 0.15 \mathrm{a}$ & $1.79 \pm 0.01 \mathrm{~b}$ \\
\cline { 2 - 4 } & pediococcus acidi lactici & $3.57 \pm 0.18 \mathrm{a}$ & $3.27 \pm 0.57 \mathrm{a}$ \\
\hline Serum CAT $(\mathrm{nm} / \mathrm{ml})$ & Control & $31.33 \pm 0.68 \mathrm{~b}$ & $22.93 \pm 1.00 \mathrm{c}$ \\
\cline { 2 - 4 } & pediococcus acidi lactici & $62 \pm 2.08 \mathrm{a}$ & $29 \pm 1.61 \mathrm{~b}$ \\
\hline Serum & Control & $161.04+23.79 \mathrm{a}$ & $117.21+19.88 \mathrm{~b}$ \\
\cline { 2 - 4 } SOD & pediococcus acidi lactici & $163.52+28.93 \mathrm{a}$ & $174.65+9.52 \mathrm{a}$ \\
\hline Serum Lipid & Control & $3.47 \pm 0.26 \mathrm{~b}$ & $10.9 \pm 0.92 \mathrm{a}$ \\
\hline peroxide $(\mathrm{nm} / \mathrm{ml})$ & pediococcus acidi lactici & $2.9 \pm 0.35 \mathrm{~b}$ & $4.1 \pm 0.67 \mathrm{~b}$ \\
\hline
\end{tabular}

$\mathrm{GSH}=$ reduced glutathion $\quad \mathrm{CAT}=$ catalase $\quad \mathrm{SOD}=$ super oxid dismutase

Values are expressed as mean \pm standard errors. Means in the same row (a-d) with different letters significantly differ at $(\mathrm{p} \leq 0.05)$.

Table 7: Effect of pediococcus acidi lactici supplementation without or with SE infection on chemical composition of broiler meat.

\begin{tabular}{lccc}
\hline parameter & Supplementation & Without infection & With SE infection \\
\hline \multirow{2}{*}{ Moisture, \% } & Control & $72.43 \pm 0.30 \mathrm{~b}$ & $74.18 \pm 0.34 \mathrm{a}$ \\
\hline & pediococcus acidi lactici & $72.65 \pm 0.34 \mathrm{~b}$ & $73.65 \pm 0.31 \mathrm{a}$ \\
\cline { 2 - 4 } Protein, \% & Control & $20.73 \pm 0.35 \mathrm{ab}$ & $19.5 \pm 0.33 \mathrm{cb}$ \\
\hline \multirow{2}{*}{ Fat, \% } & pediococcus acidi lactici & $21.6 \pm 0.38 \mathrm{a}$ & $20.38 \pm 0.34 \mathrm{~b}$ \\
\hline & Control & $3.38 \pm 0.13 \mathrm{a}$ & $3.03 \pm 0.17 \mathrm{a}$ \\
\hline \multirow{2}{*}{ Ash, \% } & pediococcus acidi lactici & $2.88 \pm 0.17 \mathrm{a}$ & $2.9 \pm 0.19 \mathrm{a}$ \\
\hline \multirow{2}{*}{ Carbohydrate, $\%$} & Control & $1.55 \pm 0.34 \mathrm{a}$ & $1.58 \pm 0.19 \mathrm{a}$ \\
\hline PH & pediococcus acidi lactici & $1.38 \pm 0.18 \mathrm{a}$ & $1.6 \pm 0.19 \mathrm{a}$ \\
\cline { 2 - 4 } & Codiococcus acidi lactici & $1 \pm 0.11 \mathrm{ab}$ & $0.8 \pm 0.09 \mathrm{~b}$ \\
\hline & Control & $0.9 \pm 0.09 \mathrm{~b}$ & $0.7 \pm 0.07 \mathrm{cb}$ \\
\hline
\end{tabular}

Values are expressed as mean \pm standard errors. Means in the same row (a-d) with different letters significantly differ at $(\mathrm{p} \leq 0.05)$

Table 8: Colonization of S. enteritidis and rate of shedding as judged by intestinal colonization.

\begin{tabular}{lccccccccccccccc}
\hline & \multicolumn{3}{c}{ Liver } & \multicolumn{3}{c}{ G.bladder } & \multicolumn{3}{c}{ spleen } & \multicolumn{3}{c}{ Intestine } & \multicolumn{3}{c}{ Total(T) } \\
\hline S. E + P & + & $\mathrm{T}$ & $\%$ & + & $\mathrm{T}$ & $\%$ & + & $\mathrm{T}$ & $\%$ & + & $\mathrm{T}$ & $\%$ & + & $\mathrm{T}$ & $\%$ \\
\hline $\mathrm{S} . \mathrm{E}$ & 2 & 15 & 13 & 2 & 15 & 13 & 3 & 15 & 20 & 5 & 15 & 33 & 12 & 60 & 20 \\
\hline Total & 6 & 15 & 40 & 5 & 15 & 33 & 5 & 15 & 33 & 9 & 15 & 60 & 25 & 60 & 42 \\
\hline S. E + P & 8 & 30 & 27 & 7 & 30 & 23 & 8 & 30 & 27 & 14 & 30 & 47 & 37 & 120 & 31 \\
\hline
\end{tabular}

$* \mathrm{~S} . \mathrm{E}+\mathrm{P}=$ S.enteritidis + Pedicoccus $*$ S.E $=$ S.enteritidis 


\section{Assiut Vet. Med. J. Vol. 60 No. 141 April 2014}

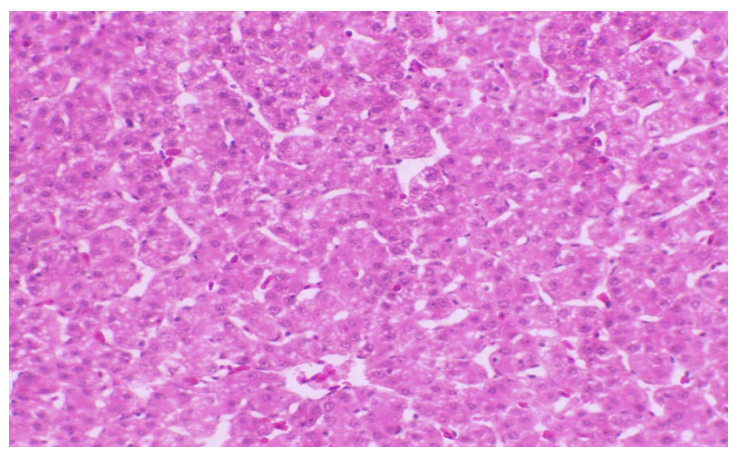

Fig. 1a. G1, the liver showing normal lobular architecture with central vein and radiating hepatic cell cords. H\&E. X 200.

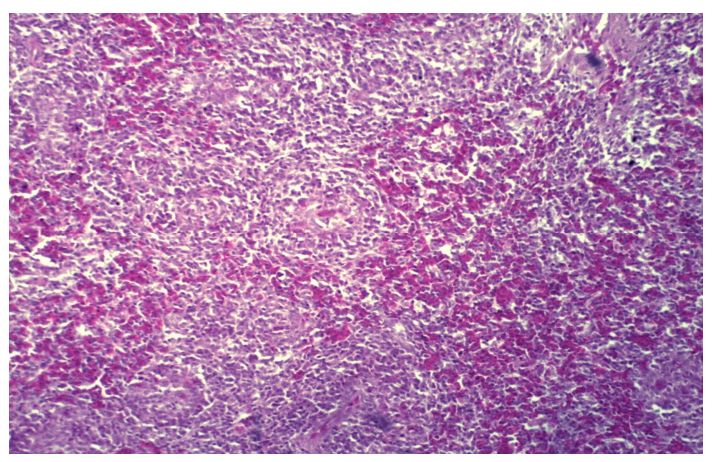

Fig.1c, G1, spleen showing normal lymphocytic cells population in the white bulb H\&E. X 100.

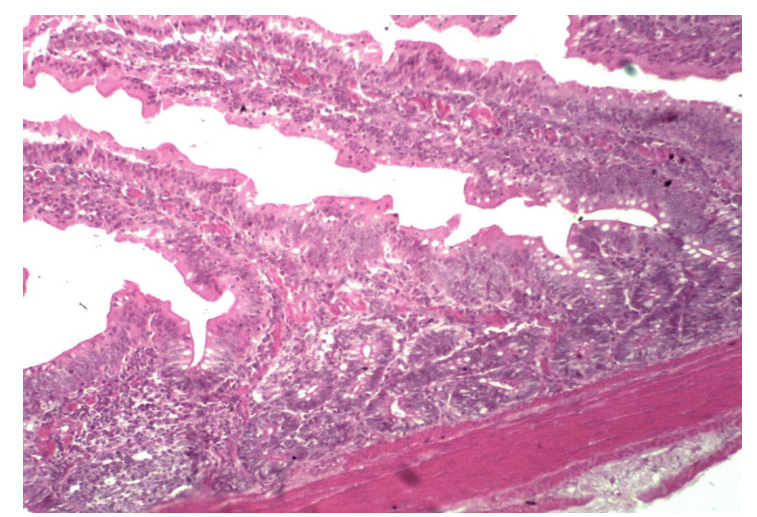

Fig.2b, G2, normal intestine with elongation of the villi. H\&E. X 100.

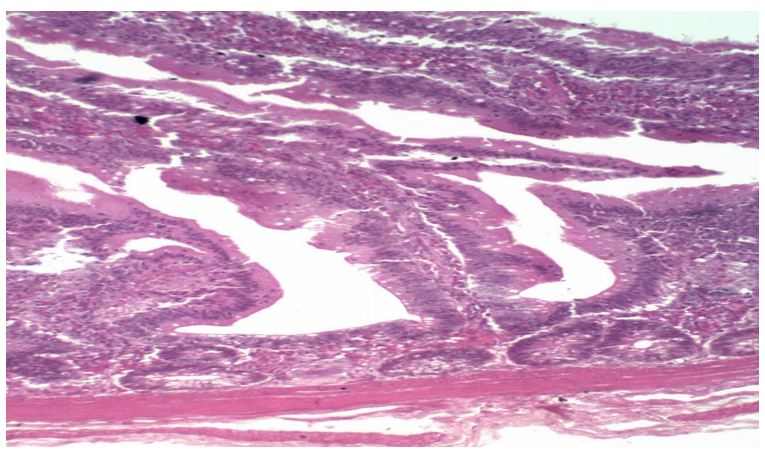

Fig.1b, G1, showing normal intestine. H\&E. X 100.

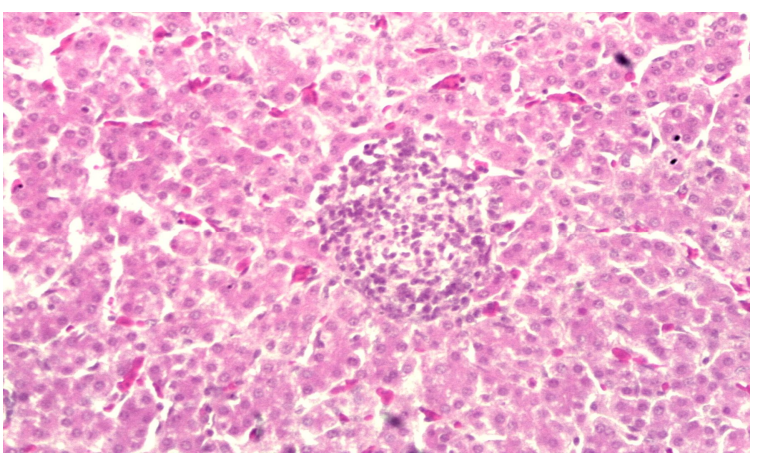

Fig.2a, G2, the liver showing small mononuclear cells collections. H\&E. X 200.

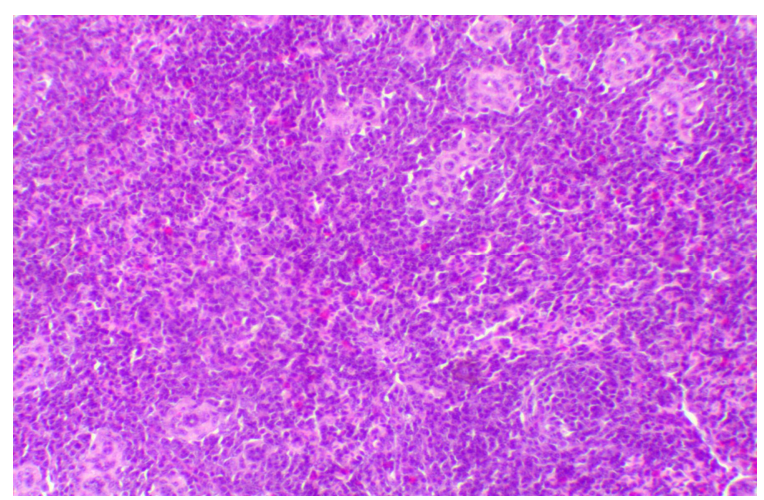

Fig.2c, G2, spleen showing increase in lymphocytic cells population in the white bulb. H\&E. X 100. 


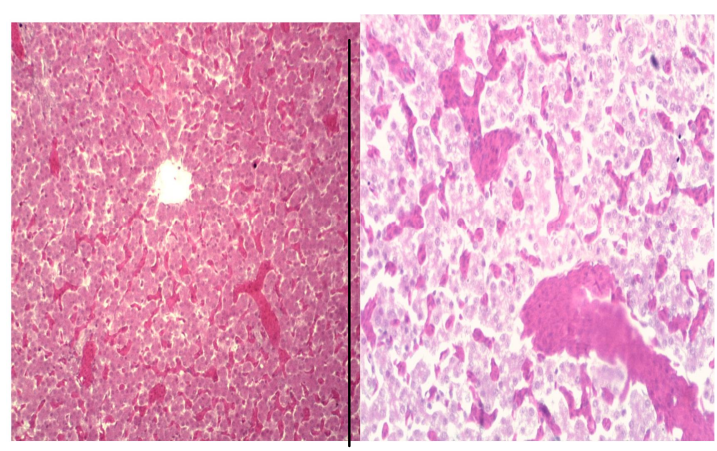

Fig.3a1,2, G3, the liver showing marked congestion. H\&E. X 100, H\&E. X 200.

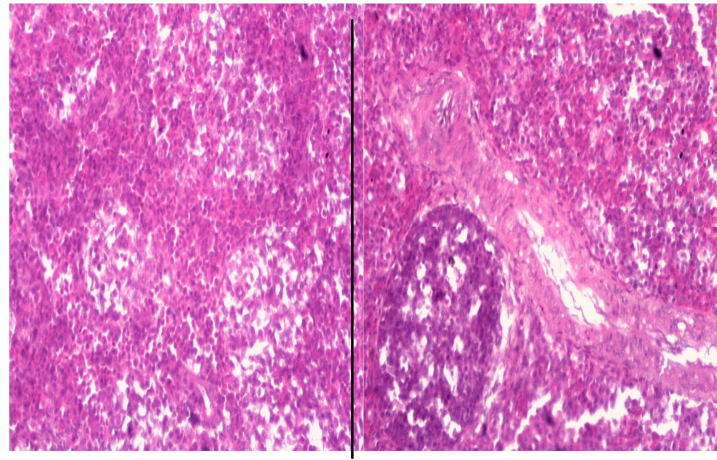

Fig.3c1,2, G3, the spleen showing moderate lymphoid depletion as well as depletion of lymphoid follicles. H\&E. X 100, H\&E. X 200.

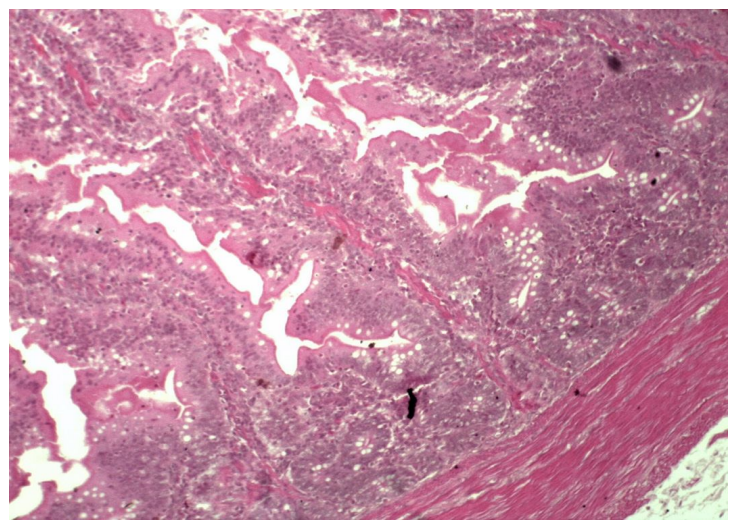

Fig.4b, G4, intestine showing mild degeneration, thickening and necrosis of villi. H\&E. X 100.

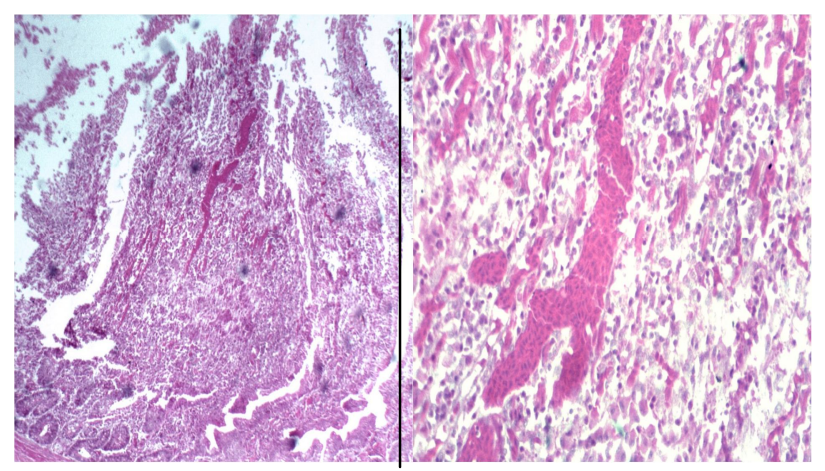

Fig.3b1,2, G3, intestine showing thickening, degeneration and necrosis of the superficial layer of the covering epithelium of mucosa together with marked congestion of the lamina prpria. H\&E. X 100, H\&E. X 200.

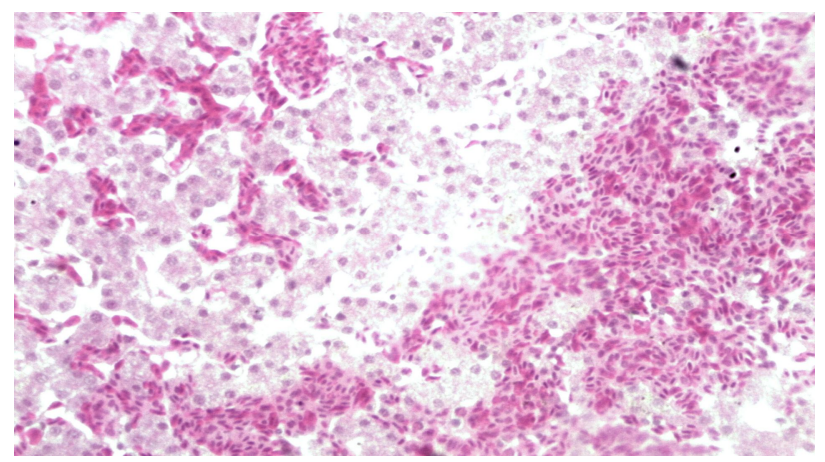

Fig.4a, G3, the liver showing focal hemorrhage. H\&E. $\mathrm{X} 100$.

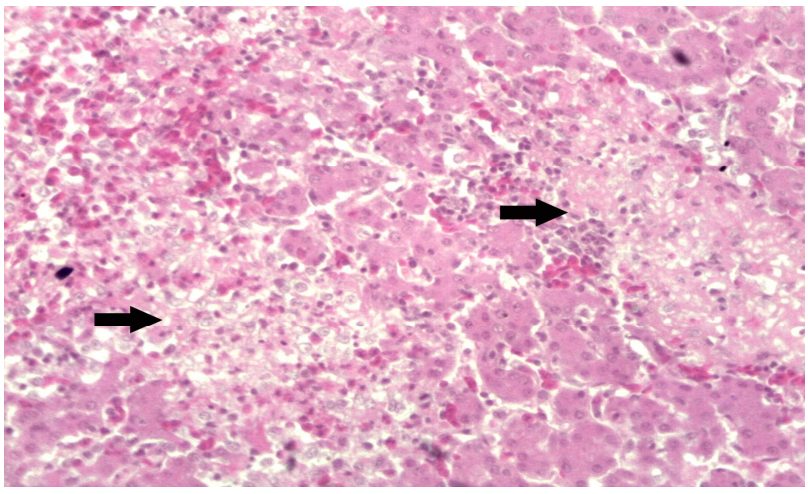

Fig.5a, G3, the liver showing focal hepatic cell necrosis infiltrated and surrounded with mononuclear cells and heterophils (arrow). H\&E. X 200. 


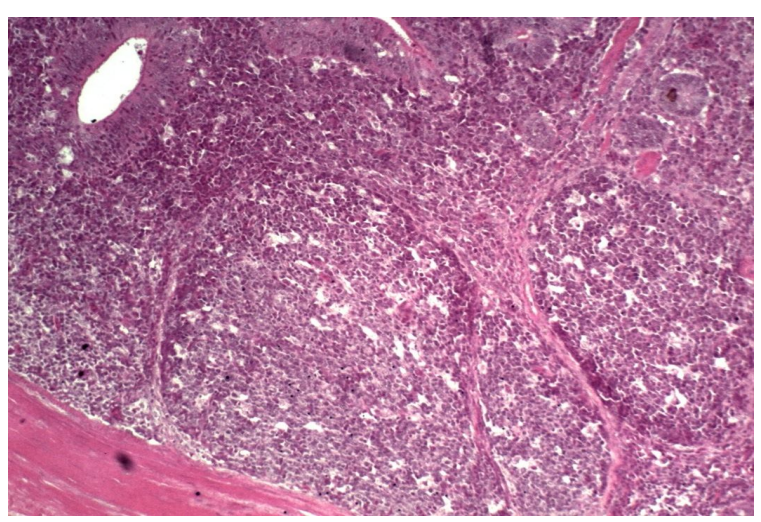

Fig.5b, G4, the intestine showing pyre's patches hyperplasia. H\&E. X 100.

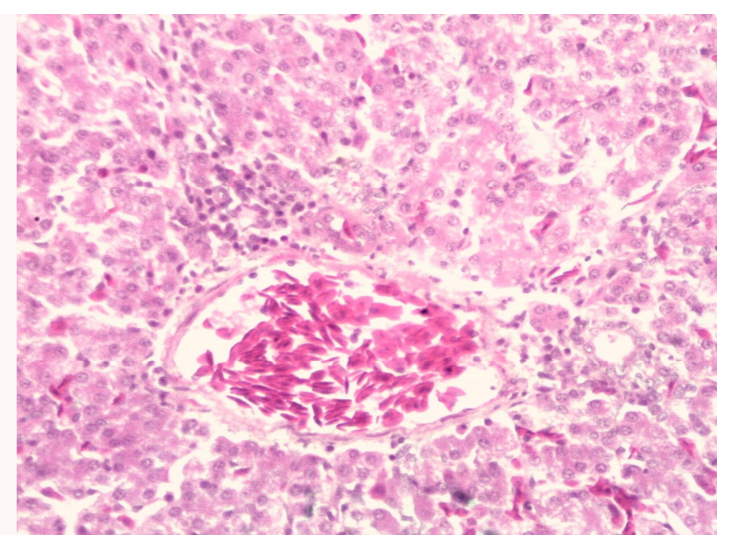

Fig.6a, G4, the liver showing mild congestion of the central vein and mild perivascular mononuclear cells collections. H\&E. X 200.

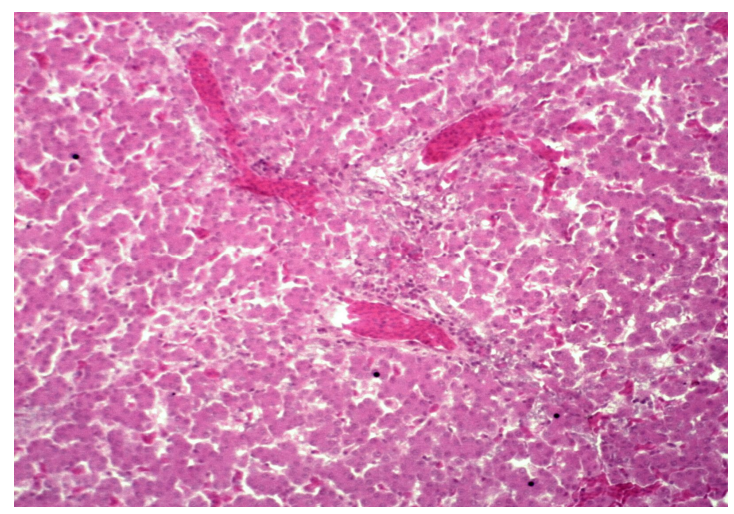

Fig.7a, G4, the liver showing mild perivascular mononuclear cells and heterophils infiltrations and moderate congestion. H\&E. X 100.

\section{DISCUSSION}

\section{Symptoms and $P$. M lesions:}

All clinical and gross pathological lesions in salmonella infected group were close with Gast and Benson (1995). The mortality rate was lower than that recorded by other workers and this may be explained by the fact that older birds were considerably less susceptible to the lethal effects of Salmonella paratyphoid and may experience intestinal colonization and even systemic dissemination without significant morbidity or mortality or the paratyphoid bacteria are not host specific and produced mortality only in young chicks (Gordon 1977).

\section{Growth performance:}

The significant $(\mathrm{P}<0.05)$ decreased in the final body weight in groups of Pediococcus with or without infection compared with the control group without infection was supported by the statement of (Djezzar et al., 2013), who reported that inclusion of Pediococcus acidilactici in the diet of broilers didnot improve the body weight, which disagreed with Tollba et al. (2007) where Pediococcus improved body weight. Kabir et al. (2004) observed an improvement in body weight when used other probiotic. Meanwhile Salmonella infected group significantly $(\mathrm{P}<0.05)$ decreased in the body weight when compared with the control without infection and the Pediococcus groups with or without infection. This finding agreed with Azza et al. (2012). The infected group by salmonella significantly decreased body weight compared with the non infected one and the Pediococcus group. The feed conversion ratio in Salmonella infected group insignificantly increased. Johri (2004) did not observe any positive effect on the FCR of the chickens when streptococcus lactis was incorporated in the feed. Meanwhile Satheesh et al. (2012) found a significant change in FCR. Taheri et al. (2010) showed a beneficial effects of dietary inclusion of pediococcus acidilactici-based probiotic. The treated birds had improved BW and FCR when compared with the control.

Antioxidant and lipid peroxidation measurements:-

The main antioxidant enzymes that constitute the first line of antioxidant enzymatic defenses include 
superoxide dismutase (SOD), catalase (CAT) and glutathione peroxidase (GPx). SOD catalyzes dismutation of superoxide radicals to hydrogenperoxide and oxygen CAT catalyzes the breakdown of hydrogen-peroxide to water and molecular oxygen. GPx is a selenium-dependent enzyme, which decomposes peroxides using the peptide glutathione (GSH) as its cosubstrate (Halliwell 2006). Meanwhile concentration of MDA in tissues and urine are generally used as a biomarker for radical-induced damage and endogenous lipid peroxidation (Wang et al., 2008).

The results of enzymatic antioxidants, GSH and MAD correlated with meat quality, histopathology and PM lesions. Significant decreased in GSH, CAT and SOD in salmonella infected group without probiotic, may be due to infection. This finding disagred with Koinarski et al. (2006), where CAT activity was increased in the infected chicks with E. acervulina and agree with Koinarski et al. (2005). They clearly showed that the chicks infected with $E$. acervulina were under oxidative stress, which was manifested primary via alterations of antioxidant enzyme activities of SOD and CAT, the reduction of some non-enzymatic antioxidants (vitamins $\mathrm{A}$ and $\mathrm{C}$ ) and increased plasma MDA concentration. The increased CAT activity indicated the highly induced capacity to scavenge hydrogen peroxide produced in the red blood cells in response to oxidative stress due to the infection. This situation may reflect the persistent oxidative stress. The increased CAT activity may be a compensatory mechanism to get rid of excess of peroxides (Halliwell and Chirico 1993). Koinarski et al. (2006) said that SOD activity was significantly decreased in blood samples from the infected chicks but blood MDA was significantly increased in the infected chicks vs the healthy ones.

Regarding the effect of probiotic, Pediococcus group without infection significantly increased CAT activity compared with the other groups and insignificantly increased SOD in the Pediococcus groups with and without infection compared with the control non infected group, insignificantly increased GSH in the Pediococcus group without infection compared with the control non infected group and the Pediococcus infected one. This finding may be due to probiotic addition Castex et al. (2010) showed that the infected shrimps with Vibrio nigripulchritudo previously fed with the probiotic enriched diet (Pediococcus acidilactici) maintained the levels of their antioxidant defenses compared to the control over the 72-hour challenge period. Indeed, TAS and SOD, Gpx and CAT activities in the digestive gland did not decrease after infection as observed in the control group. Lactic Acid Bacteria (LAB) have antioxidant activities (Kullisaar et al., 2002). Some studies showed an enhancement of total antioxidant status (TAS) in blood of humans fed LABs (Kullisaar et al., 2003).
MAD significantly $(\mathrm{P}<0.05)$ increased in the salmonella infected group. This may be attributed to salmonella infection. This finding agree with Koinarski et al. (2006) where one of the main blood lipid peroxidation products (MDA) "a marker of radical-induced damage" was statistically significantly $(\mathrm{P}<0.05)$ increased in the E. acervulina infected chicks. Increased concentrations of lipid peroxidation endproducts have been used as indicators of ROS-derived damage in biological systems (Halliwell and Chirico 1993). Mathew et al. (2007) reported a concomitant increase in lipid peroxidation and a drop in antioxidant enzyme activities of SOD, CAT, Gpx and Glutathion-S- transferase in the digestive gland, muscle and haemolymph of $P$. monodon following infection with white spot syndrome virus (WSSV). The mucosal pathology of Salmonella typhimurium infection may in part be due to the excessive production of reactive oxygen species (ROS) (Mehta et al., 1998).

Pediococcus group without infection insignificantly decreased MDA compared with the control non infected group and the Pediococcus infected one, this finding may be due to Pediococcus acidilactici. This finding agree with Castex et al. (2010) where MDA and carbonyl protein were significantly $(\mathrm{P}<0.05)$ lower in the probiotic group compared to the infected control at $24 \mathrm{~h}$. post infection of Litopenaeus stylirostris under infection with Vibrio nigripulchritudo.

\section{Chemical analysis of meat: -}

Meat can be defined as the product that results from the continuous changes that occur in muscle after the death of the animal (Castillo et al., 2013). Poultry meat is particularly high in quantities of valuable protein, essential amino acids, fat, essential fatty acids, vitamins and minerals, which come from high quality concentrated food and therefore plays an important role in human nutrition (Givens 2005). Water, proteins and fat are major constituents of the meat and their qualitative and quantitative relationship determines the quality, in the other words, nutritional value of meat (Ivanovic et al., 2012).

The chemical composition of broiler meat showed the average water content was significantly decreased in the control group without infection and in Pediococcus group without infection compared with control infected group and Pediococcus infected one. This result agreed with Ivanovic et al. (2012) where addition of probiotic increased water content in drumsticks of broiler but disagreed with Sazedul et al. (2010). While protein significantly increased in Pediococcus group without infection compared with salmonella infected group and Pediococcus infected one, and increased unsignificantly control group without infection. This findings agreed with finding of Ivanovic et al. (2012). Analyzing the chemical 
composition of breast meat they found that the total protein content was statistically significantly higher ( $\mathrm{P}$ $<0.05$ ) after the addition of probiotics. Fat \% showed lower $\%$ in groups receiving Pediococcus with or without infection compared with control groups with or without infection without significance. This findings agreed with Ignatova et al. (2009) that the probiotic decreased fat in breast meat of experimental group compared to control group. The supplementation of probiotics (Lactobacillus acidophilus and Streptococcus faecium) to broiler diets was reported (Mahajan et al., 2000) to increase moisture, protein, ash, water-holding capacity (WHC), emulsion capacity and stability in broiler meats. Some authors reported advantages of probiotic administration on meat quality (Corrêa et al., 2000; Vargas et al. 2002), whereas others did not observe improvement when probiotics were used (Owings et al., 1990; Quadros et al., 2001). Probiotics were reported to prevent colonization gut by pathogens like Escherichia coli and Salmonella (Juven et al., 1991). Probiotics may help in minimizing stress and improving meat quality regimen of broilers. Also supplementation of probiotics in broiler ration improved the meat quality both at prefreezing and postfreezing storage (Kabir 2009).

Significant increased in $\mathrm{PH}$ in salmonella infected group compared with control without infection and Pediococcus without infection and in Pediococcus infected one, were reported with insignificant decreased in $\mathrm{PH}$ in Pediococcus without infection group compared with control group without infection. These findings disagreed with Aksu et al. (2005) where the use of probiotic Saccharomyces cerevisiae $\left(4 \times 10^{8} \mathrm{cfu} / \mathrm{g}\right)$ in broiler diets increased $\mathrm{pH}$ values, and the highest $\mathrm{pH}$ values occurred in the $0.2 \%$ group. Pelicano et al. (2005) measured $\mathrm{pH} 5 \mathrm{~h}$ after the slaughter and found no statistical significant difference between meat samples from chickens that did not receive probiotics. Insignificant decreased in ash $\%$ in the Pediococcus groups with or without infection compared with the control groups with or without infection were recorded. This finding agree with Ignatova et al. (2009). Carbohydrate \% insignificant decreased in salmonella infected group, and Pediococcus group without infection compared with control without infection but significantly $(\mathrm{P}<$ 0.05) decreased in Pediococcus with infection compared with control without infection. This finding may be due to Pediococcus and/or infection. Some studies have demonstrated that meat shelf-life and quality can be improved by natural antioxidants added in the preslaughter stages, incorporating natural antioxidants in animal diets. Thus, among the positive effects of natural antioxidants on meat characteristics were retarding lipid oxidation, color loss, and microbial growth (Velasco and Williams 2011).

\section{S. enteritidis colonization:}

The colonization of $S$. enteritidis differed in different organs. Similar observations were reported by Barrow (1991) and Gorham et al. (1991). Several experiments had demonstrated that prevention of Salmonella colonization in chickens can be achieved by many treatments. Probiotics was one of them (Johannsen et al., 2004). This was true as in the present work $S$. enteritidis was capable to colonize different organs with different rates. This could be supported by the findings of Tollba et al. (2007) and Jamila et al. (2011) who reported that probiotics, suppressed the counts of pathogenic intestinal bacteria and decreased colonization of salmonella.

\section{Histopathological findings of chicken supplemented with Pediococcus and challenged with salmonella infection:}

The finding in control group without infection and Pediococcus without infection agreed with Taheri et al. (2010). The effect of Pediococcus acidilacticibased probiotic on intestinal villus height of broiler chickens was increased villus height in duodenum and ileum when compared with control. Pediococcus acidilactici enhanced the colonization and adhesion of probiotics on the surface of intestines besides increasing the density, length and width of intestinal villus resulting in better performance and meat quality in broilers (Satheesh et al., 2012).

Microscopic changes in liver which included Congestion and haemorrhages, isolated necrotic foci in hepatic parenchyma along with infiltration of leucocytes predominantly mononuclear cells and heterophils were also reported by Freitas et al. (2007) and Garcia et al. (2010). Depletion of lymphocytes and focal necrotic changes were also reported by Mohammadi et al. (1976) and Freitas et al. (2007). Prasanna et al. (2001) also reported a congestion of mucosal vessels, marked goblet cell hyperplasia, mild to moderate infiltration of heterophils and mononuclear cells in the lamina propria of the villi of intestines.

\section{REFERENCES}

A.O.A.C. (1990): Official Methods of Analysis, 15th Ed. Association of Official Analysis of Chemists, Washington D.C.

Aksu, M.I.; Karaoğlu, M.; Esenbuğa, N.; Kaya, M.; Macit, M. and Ockerman, H.W. (2005): Effect of a dietary probiotic on some quality characteristic of raw broiler drumticks and breast meat. Journal of Muscle Foods 16, 306-317.

Ashru, K. and Sinha, (1971): Determination of catalase activity in white blood. Advance in Enzymology and related areas of Molecular Biology, 27: 380 . 
Association of Official Analytical Chemists "AOAC" (2000): Official methods of analysis. 13th Ed., w. Horwitz.w, (Editor), Academic Press, Washington, D.C., USA.

Azza, H.A.; Kamel, H.H.; Walaa, M.A.; Olfat, S.H.M. and Amira, H.M. (2012): Effect of Bactocell ${ }^{\circledR}$ and Revitilyte-Plustm as Probiotic Food Supplements on the Growth Performance, Hematological, Biochemical Parameters and Humoral Immune Response of Broiler Chickens. World Applied Sciences Journal 18 (3): 305-316.

Barrow, P.A. (1991): Experimental infection of chicken with S.enteritidis. Avian Pathol. 20: 145-153.

Beuge, JA. and Aust, SD. (1978): Microsomal lipid peroxidation in Colowick SP, and Kaplan NO. (eds): Methodes in Enymology, Academic Press, New York, vol 52, pp. 302-310.

Beutler, E.; Duran, O. and Kelly, MB. (1963): Improved method for the determination of blood glutathione. J. Lab. Clin. Med.; 61: 882-888.

Castex, M.; Lemaire, P.; Nelly Wabete, N. and Liet Chim, L. (2010): Effect of probiotic Pediococcus acidilactici on antioxidant defences and oxidative stress of Litopenaeus stylirostris under Vibrio nigripulchritudo challenge. Fish \& Shellfish Immunology April Volume 28, Issue 4, April 2010, Pages 622-631.

Castillo, C.; Pereira, V.; Abuelo, Á. and Hernández, $J$. (2013): Effect of Supplementation with Antioxidants on the Quality of Bovine Milk and Meat Production. The Scientific World Journal Volume 2013, Article ID 616098, 8 pages.

Corrêa, GSS.; Gomes, AVC.; Corrêa, AB. and Salles, $A S$. (2000): Desempenhode frangos decorte alimentados com diferentes promotores decrescimento. In: Reunião Anual da SBZ, Viçosa. p. 37.

Djezzar, R.; Benamirouche, K.; Baazize-Ammi, D.; Khoubei, A.; Merroukhi, A.; Maghni, E. and Guetarni, D. (2013): Impact of Dietary Supplementation with Pedicoccus Acidilactici on Zootechnical and Sanitary Performances of Broilers in Algeria. J. Anim. Sci. Adv., 3(4): 157-164.

Duncan, D.B. (1955): Multiple Ranges and Multiple F - test. Biometerics, 11:1-42.

Farthing, MJG. (2004): Bugs and the gut: An unstable marriage. Best Prac. Res. Clin. Gastroenterol. 18: 233-239.

Ferguson, RMW.; Merrifield, DL.; Harper, GM.; Rawling, MD.; Mustafa, S.; Picchietti, S.; Balcázar, JL. and Davies, SJ. (2010): The effect of Pediococcus acidilactici on the gut microbiota and immune status of on-growing red tilapia (Oreochromis niloticus). Journal of
Applied Microbiology Volume 109, Issue 3, pages 851-862, September.

Freitas Neto, O.C.; Arroyave, W.; Alessi, A.C.; Fagliari, J.J. and Berchleri, A. (2007): Infection of commercial laying hens with Salmonella Gallinarum. Clinical, anatomopathological and haematological studies. Revista Brasileira de Ciência Avícola, 9, 133-141.

Garcia, K.O.; Santana, A.M.; Freitas, N.O.C.; Simplício, K.M.M.G.; Alessi, A.C.; Júnior, A.B. and Fagliari, J.J. (2010): Experimental infection of commercial layers using a Salmonella enterica sorovar Gallinarum strain: blood serum components and histopathological changes. Brazilian Journal of Veterinary Pathology, 3, 111-117.

Gast, K.R. and Benson, T.S. (1995): The comparative virulence for chicken of S.enteritidis PT4 isolates and isolates of phage types commonly found in the USA. Avian Dis., 39:567-574.

Gatesoupe, F. (1999): The use of probiotics in aquaculture: a review. Aquaculture 180: 147-165.

Georgieva, NV.; Koinarski, $V$. and Gadjeva, $V$. (2006): Antioxidant status during the course of Eimeria tenella infection in broiler chickens. The Veterinary Journal 172, 488-492.

Givens, D.I. (2005): The role of animal nutrition in improving the nutritive value of animal-derived foods in relation to chronic disease. P. Nutr. Soc., 64: 395-402.

Gordon, R.F. (1977): Avian Salmonellosis. In: poultry diseasePp: 24-33. Bailliare Tindall, London.

Gorham, S.L.; Kadavil, K.; Lambert, H.; Vaughaan, E.; Pert, B. and Abel, J. (1991): persistence of $S$. enteritidis in young chickens. Avian Pathol., 20: 433-437.

Halliwell, B. and Chirico, S. (1993): Lipid peroxidation: its mechanism, measurement and significance. Amer. J. Clin Nutr 1993, 57, 715-725.

Halliwell, B. (2006): Reactive species and antioxidants redox biology is a fundamental theme of aerobic life. Plant Physiol. 141, 312-322.

Ignatova, M.; Sredkova, $V$. and Marasheva, $V$. (2009): Effect of dietary inclusion of probiotic on chickens performance and some blood indices. Biotechnolo. Ani. Husbandry 25(5-6): 1079-1085.

Ivanovic, S.; Baltic, M.; Popov-Raljic, J.; Pisinov, B.; Maslic-Strizak, D.; Stojanovic, $Z$. and Pavlovic, I. (2012): The effect of different probiotics on broiler meat Quality. African Journal of Microbiology Research Vol. 6(5), pp. 937-943, 9 February.

Jamila, K. Adam.; Bharti, Odhav and Suresh, B.N.K. (2011): Probiotics: Recent Understandings and 
Biomedical Applications. Current Trends in Biotech. and Pharmacy Vol. 6 (1) 1-14.

Jensen, C.; Skibsted, L.H.; Jakobsen, K. and Bertelsen, G. (1995): Supplementation of broiler diets with all-rac-or a mixture of natural source RRR-tocopheryl acetate. 1. Effect on the oxidative stability of raw and precooked broiler meat products. Poultry Science, 74: 2048-2056.

Johannsen, S.A.; Griffith, R.W.; Wesley, I.V. and Scanes, C.G. (2004): Salmonella enterica serovar typhimurium colonization of the crop in the domestic turkey: Influence of probiotic and prebiotic treatment (Lactobacillus acidophilus and lactose). Avian Dis. 48:279-286.

Johri, T.S. (2004): Dietary additives for enhancing nutritional value of feeds. FAO-Roma.

Juven, BJ.; Meinersmann, RJ. and Stern, NJ. (1991): Antagonistic effects of Lactobacilli and Pediococci to control intestinal colonization by human entero-pathogens in live poultry. J. Appl. Bacteriol. 70(2): 95-103.

Kabir, S.M.L. (2009): Effect of probiotics on broiler meat quality. African Journal of Biotechnology Vol. 8 (15), pp. 3623-3627, 4 August.

Kabir, S.M.L.; Rahman, M.M.; Rahman, M.B. and Ahmed, S.U. (2004): The dynamic of probiotics on growth performance and immune response in broilers. Poult. Sc.; 3(5): 361-364.

Koinarski, V.; Georgieva, N.; Gadjeva, V. and Petkov, P. (2005): Antioxidant status of broilerchickens infected with Eimeria acervulina. Revue Med Vet 2005, 156, in press.

Koinarski, V.; Gabrashanska, M.; Georgiva, N. and Petkov, P. (2006): Antioxidant parameters in Eimeria Acervulina infected chicks after treatment with a new zinc compound. Bull Vet Inst Pulawy 50, 55-61.

Kullisaar, T.; Songisepp, E.; Mikelsaar, M.; Zilmer, K.; Vihalemm, T. and Zilmer, M. (2003): Antioxidative probiotic fermented goats' milk decreases oxidative stress-mediated atherogenicity in human subjects. British Journal of Nutrition, 90: 449-456.

Kullisaar, T.; Zilmer, M.; Mikelsaar, M.; Vihalemm, T.; Annuk, H.; Kairane, C. and Kilk, A. (2002): Two antioxidative lactobacilli strains as promising probiotics. International Journal of Food Microbiology, 72: 215-224.

Mahajan, P.; Sahoo, J. and Panda, P.C. (2000): Effect of probiotic (Lacto-Sacc) feeding and season on poultry meat quality. Indian Poult. Sci. Assoc. 35, 297-301.

Mathew, S.; Kumar, K.A.; Anandan, R.; Nair, P.G.V. and Devadasan, K. (2007): Changes in tissue defence system in white spot syndrome virus (WSSV) infected Penaeus monodon. Comparative Biochemistry and Physiology, Part C; 145: 315-320.
Mehta, A.; Singh, S. and Ganguly, NK. (1998): Impairment of intestinal mucosal antioxidant defense system during Salmonella typhimurium infection. Dig Dis Sci. 1998 Mar; 43(3): 646-51.

Mohammadi, H.; Hill, R.; Smith, R.I.M. and Licence, S.T. (1976): Observations on some changes during acute S. Gallinarum infection in chicks. Avian Pathology. 5, 71-80.

Nishikimi, M.; Roa, N.A. and Yogi, K. (1972): Biochem. Bioph. Res. Common., 46, 849-854.

NRC, (1994): Nutrient requirements of poul., 9th ed. National Academy of Sci., Washington, DC.

Owings, WJ.; Reynoldas, DL.; Hasiak, RJ. and Ferket, PR. (1990): Influence of dietary supplementation with Streptococcus faecium M-74 on broiler body weight, feed conversion, carcass characteristics, and intestinal microbial colonization. Poult. Sci. 69: 1257-1264.

Pearson, D. (1984): Chemical Analysis of Foods. 9th Ed, Publishing Co. Churchill Livingstone, Edinburgh, London, United Kingdom.

Pelicano, ERL.; De Souza, PA.; De Souza, HBA.; Oba, A.; Boiago, MM.; Zeola, NMBL.; Scatolini, AM.; Bertanha, VA. and De Lima, TMA. (2005): Carcass and cut yields and meat qualitative traits of broilers fed diets containing probiotics and prebiotics. Brazilian J.Poultry Sci., 7: 169-175.

Prasanna, K.; Somvanshi, R. and Paliwal, O.P. (2001): Experimental fowl typhoid and Pullorum disease infection in chicken: Histopathological and ultrastructural studies on small intestine and liver. Indian Journal of Veterinary Pathology, 25, 18-20.

Quadros, ARB.; Kiefer, C.; Ribeiro, NLC. and Zink, LA. (2001): Características qualitativas da carne de suínos alimentados com rações contendo ounão probióticos. In:XXXVIII Reunião Anual da SBZ, Piracicaba. Anais. Piracicaba, pp. 794-795.

S.P.S.S. (1997): Statistical package for the social sciences, Revisions 6, spss Inc, Chicago, USA.

Satheesh, Y; Reddy K. Kondal; Gupta, P.S.P.; Mallikarjuna, P.V.R.; Reddy Y. Ramana and Kumar M. Kishan (2012): Effect of feeding Pediococcus acidilactici on performance of broiler chicken and microstructures of intestinal villus. Indian Journal of Poultry Science. Volume: 47, Issue: 3, 357-362.

Sazedul, KS.; So-Ri, P.; Gwi-Man, K. and Chul-Ju, Y. (2010): Hamcho (Salicornia herbacea) with probiotics as alternative to antibiotic for broiler production. J. Med. Plants Res., 4:415-420.

Seleim, R.S. (1999): Specificity of outer membrane protein antigen for detecting $\mathrm{S}$. enteritidis antibodies in chicken serum. J. Egy. Vet. Med. Ass. (No.2\&3); 383-394.

Sepp, T.; Karu, U.; Blount, JD.; Sild, E.; Männiste, $M$. and Horak, $P$. (2012): Coccidian Infection 
Causes Oxidative Damage in Greenfinches. PLoS ONE 7(5): e36495.

Taheri, HR.; Moravej, H.; Malakzadegan, A.; Tabandeh, F.; Zaghari, M.; Shivazad, M. and Adibmoradi, M. (2010): Efficacy of Pediococcus acidlactici-based probiotic on intestinal Coliforms and villus height, serum cholesterol level and performance of broiler chickens. African Journal of Biotechnology Vol. 9(44), pp. 7564-7567.

Tesoriere, L.; D’Arpa, D.; Butera, D.; Pinataudi, A.M.; Allegra, M. and Livrea, M.A. (2002): Exposure to malondialdehyde inducts an early redox unbalance preceding membrane toxicity in human erythrocytes. Free Radical Research, 36: 89-97.

Tollba, A.A.H.; Wagdy, A.Z. and Shabaan, S.A.M. (2007): Improvement of Fayoumi laying hens performance under hot climate conditions: 1Probiotic and Prebiotic. Egypt, Poult. Sci. Vol (27) (I): (1-20).
Vankampen, E.J. (1961): Determination of haemoglobin. Clin. Chem. Acta, 5: 719-720.

Vargas Jr JG; Toledo, RS.; Albino, LFT.; Rostango, HS.; O liveira JE and Carvalho, DCO. (2002): Características de carcaça defrango de corte, submetidos a rações contendo probióticos, prebióticos e antibióticos. In: XXXIX Reunião Anual da SBZ, Recife. Anais. Recife, CD ROM.

Velasco, $V$. and Williams, P. (2011): Improving meat quality through natural antioxidants, Chilean Journal of Agricultural Research, vol. 71, pp. 313-322.

Wang, Y.Z.; Xu, C.L.; An, Z.H.; Liu, J.-X. and Feng, $J$. (2008): Effect of dietary bovine lactoferin on performance and antioxidant status of piglets. Anim. Feed Sci. Technol. 140, 326-336.

Weber, G.M. and Antipatis, C. (2001): Pork meat quality and dietary vitamin E. Second International Virtual Conference on Pork Quality.
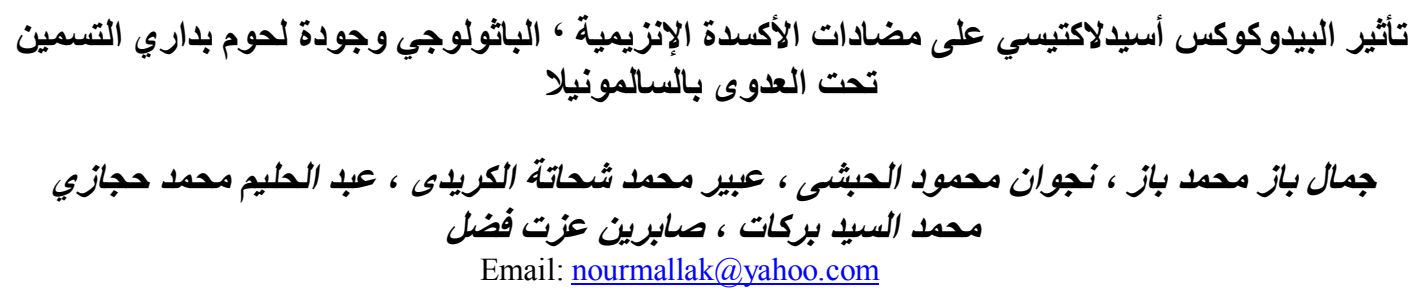

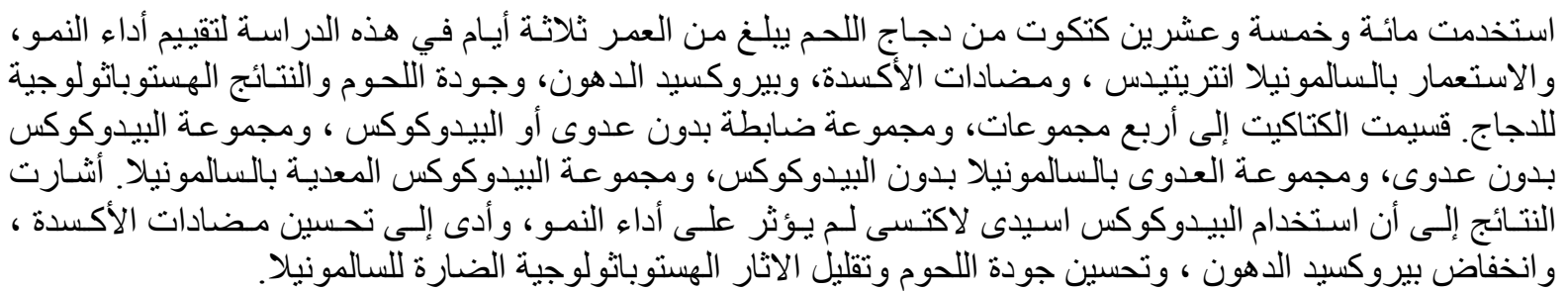

